\title{
Design and simulation hybrid filter for 17 level multilevel inverter
}

\author{
Marshal Andrea Hutabarat, Syafruddin Hasan, Ali Hanafiah Rambe, Suherman
}

Electrical Enginering Department, Universitas Sumatera Utara, Indonesia

\begin{tabular}{|c|c|}
\hline Article Info & ABSTRACT \\
\hline Article history: & \multirow{8}{*}{$\begin{array}{l}\text { The increasing of renewable energy applications such as solar cells, } \\
\text { wind power, ocean thermal and HVDC (high voltage direct current) cause } \\
\text { increment in the use of the inverter circuit. Harmonics that are generated } \\
\text { by the inverter have negative impacts on the electrical equipment; harmonics } \\
\text { cause excessive heat and may shorten the life of electrical equipment. } \\
\text { A multilevel inverter is an arranged of cascaded inverters which aims } \\
\text { to reduce total harmonic distortion (THD). This paper proposes the design } \\
\text { of } 17 \text { levels of a single-phase cascaded multilevel inverter with a hybrid filter } \\
\text { insertion. By using PSIM simulator, the hybrid filter is proven reducing THD } \\
\text { better than single pulse width modulation (SPWM) inverter. Installation } \\
\text { of the hybrid filter is able to fix a maximum of } 0.23 \% \text { THDv and a maximum } \\
\text { of } 1.05 \% \text { THDi. Hybrid filter installation reduces the value of THD } \\
\text { to comply with IEEE 519-2014 standard. }\end{array}$} \\
\hline Received Jan 11, 2018 & \\
\hline Revised Oct 24, 2019 & \\
\hline Accepted Jan 10, 2020 & \\
\hline Keywords: & \\
\hline $\begin{array}{l}\text { Cascaded multilevel inverter } \\
\text { Hybrid filter }\end{array}$ & \\
\hline SPWM inverter & \\
\hline THD & \\
\hline
\end{tabular}

This is an open access article under the CC BY-SA license.

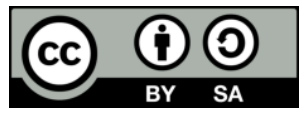

\section{Corresponding Author:}

Marshal Andrea Hutabarat,

Department of Electrical and Computer Engineering,

University of North Sumatera,

Abdul Hakim St. No.1, Padang Bulan, Kec. Medan Baru, Kota Medan, Sumatera Utara 20222, Indonesia.

Email: Marshaladre123@gmail.com

\section{INTRODUCTION}

Population increases every year. This growth is directly proportional to the need for electrical energy, which is also growing [1]. As energy sources are limited, the use of renewable energy becomes an alternative to satisfy the need for electrical energy. Since electrical waveform generated by renewable sources such as solar cells is dominated by direct current (DC), the used of inverter becomes frequent to convert DC Voltage to AC Voltage. Such devices have been widely available in the market and have been used for many applications [2]. However, the AC waveform generated by the inverters is often costly, poor quality output and containing high harmonic indices [3]. Many researchers have done real works in designing inverter. For instance, Arif et al [4] focused on the multi-level topology, while Jidin et al [5] used space vector modulation to improve the output voltage. Another researcher [6] reduced the total harmonics distortion (THD) by adjusting the inverter itself. Therefore, this paper focuses on the use of filters in inverter. This paper proposes a hybrid filter insertion on the output of the inverter. It is expected by doing so, THD complies with the IEEE 519-2014 standard requirement [7]. The proposed filter is a hybrid filter, which is a combination of two filters: an active filter and a passive filter $[8,9]$. Hybrid filters have more benefits than passive filters in filtering harmonics, both from the viewpoint of usefulness and performance, particularly for extraordinary power applications $[10,11]$.

The active filter is delineated by performing similar to resistors during harmonic frequencies, resulting in harmonic elimination across distribution channels [12]. The active filter works by injecting harmonic current into the circuit so the inverter can work under different load conditions. It is applied to 
compensate voltage harmonic in series with active power filter or to compensate current harmonic in shunt with active power filter [13, 14]. The active filter injects the compensation current into the circuit. Therefore, the THDi in the circuit improves. The passive filter works on a particular tuned frequency so that harmonic current is passed through a passive filter and the load receives voltage and current with muted harmonics.

The LCL filter is a popular solution for voltage source converter connected to the network for its ability to achieve better harmonic switching mitigation [15-17]. Previously, the L filter was used to reduce the harmonic content at high switching frequencies, by inserting it in between the grid source and the converter's poles $[18,19]$. However, to meet the power quality standard, a significant value of inductor is expected [20]. Thirumoorthi \& Yadaiah state that LC filter is the simplest method to mitigate the reactive power and harmonic current [21]. Nevertheless, its simple approach also has limitations [22]. Therefore, to gain maximum results, the LCL filter is installed as a passive filter in this work.

The IEEE 519-2014 allows the permitted THD level by a maximum value of $8 \%$. THD level higher than $8 \%$ may generate non-sinusoidal output that injects negative influences on the loads. High harmonic values increase the temperature of electronic devices, which become rapidly hot. The manual pulse settings cause unstable generated frequencies [23].

\section{CASCADED MULTILEVEL INVERTER}

The output voltage generated by the inverter is ideally sinusoidal [24]. However, in reality, it contains harmonics that generate non-sinusoidal output waveform. The non-sinusoidal transients are still acceptable for low and medium power applications. Nevertheless, minimal inverter requirements for harmonics and sinusoidal voltages are needed for high power applications [25].

Figure 1 shows three different inverter output voltages: + VDC, 0 and -VDC. DC source is connected to the AC output side by various combinations of four switches: S1, S2, S3, and S4. For instance, by turning ON S1 and S4 yield + VDC, turning ON S2 and S3 yield -VDC and turning OFF all switches yield 0 voltage. The output voltage is the sum of the voltages generated by each inverter level. The output voltage level is $2 n+1$, where $n$ is the number of DC voltage sources.

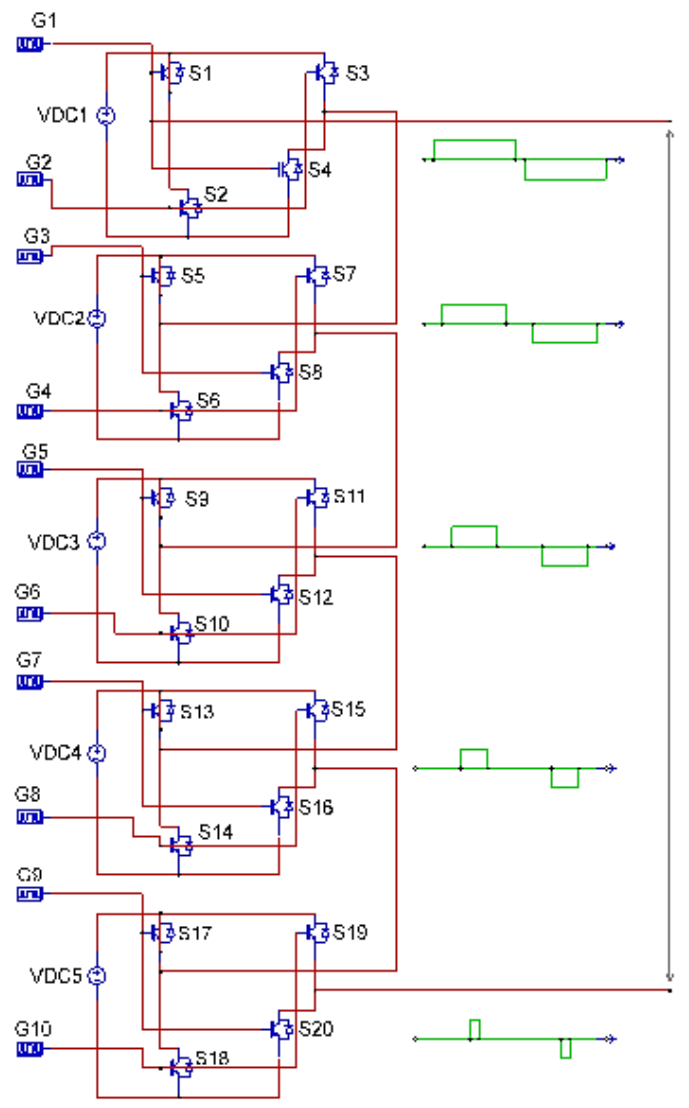

(a)

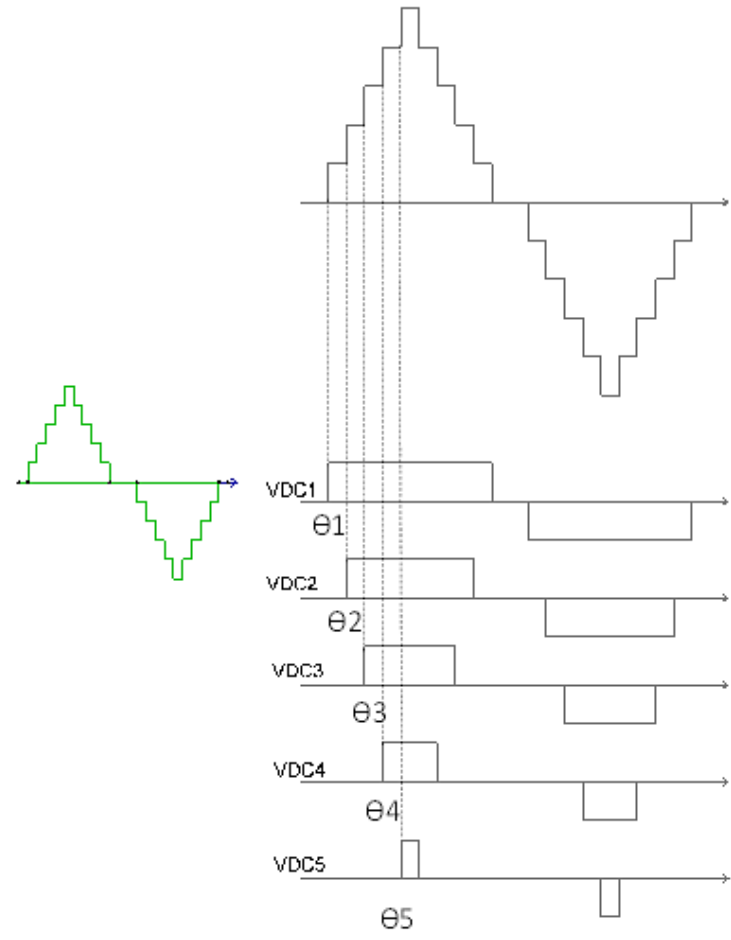

(b)

Figure 1. Cascaded multilevel inverter, (a) Inverter circuit, (b) Output waveform 
Since the inverter has five DC sources, the output voltage level will be 11 levels of cascaded multilevel inverter. The higher the levels, the better the quality of the output [26]. The first H-bridge produces VDC1 Volt during time $\Theta 1$. The second H-bridge provides VDC2 Volt during time $\Theta 2$ and so on until VDC5. The sum of the five inverter outputs synthesizes the phase output voltage, VOut=VDC1+VDC2+VDC3+VDC4+VDC5, as expressed by (1) [1], where $\mathrm{V}(\omega \mathrm{t})$ is the output voltage, VDC is DC input voltage source and $\theta$ is IGBT turning point.

$$
V_{(\omega t)}=\frac{4 V_{D C}}{n \pi} \sum_{n=1,3,5 \ldots}^{\infty}[\operatorname{Cos}(n \theta 1)+\operatorname{Cos}(n \theta 2)+\cdots+\operatorname{Cos}(n \theta n)] \operatorname{Sin}(n \omega t)
$$

\section{CIRCUIT DESIGN}

\subsection{Design 17 level cascaded multilevel inverter}

The multilevel inverter cascaded circuit uses $8 \mathrm{H}$-bridge inverters. Each level works on $30 \mathrm{VDC}$ voltages. Each H-bridge inverter uses four pieces insulated gate bipolar transistors (IGBTs). IGBT is a semiconductor component that is widely used as a switch that combines high-efficiency switching [27]. IGBT is a transistor that designed with high impedance, so it does not overload the control circuit, especially the driver part. Different from any previous power semiconductors, the ON and OFF conditions of IGBT do not produce power losses.

The working pulse/angle setting of IGBT uses a pulse generator. In PSIM software simulator, this setting is available by using a gating block for the switch. Gating block switch 1 (G1) is used for IGBT 1 and 4 drivers. Gating block switch 2 (G2) is used as IGBT 2 and IGBT 3. The G1 driver is set at the ignition angle from $5^{\circ}$ to $175^{\circ}$ for positive pulses. G2 is set on the ignition angle from $185^{\circ}$ to $355^{\circ}$ for negative pulses. Setup for all drivers is displayed in Table 1.

After adjusting all gating blocks as described in Table 1, the voltage probe is added to evaluate the waveform generated by the cascaded multilevel inverter circuit. The whole circuit of the multilevel cascaded inverter is shown in Figure 2. The designed circuit is assembled by 32 IGBTs, connected to 8 voltage source of 30 VDC. After simulation executed, the output voltage generated by this circuit and its THD values are obtained. Figure 3 shows the waveforms and harmonics spectrum of the output voltage. The effective root mean square (rms) value of the output voltage (Vrms) is $153.49 \mathrm{~V}$ and the total harmonic distortion (THDv) produced by this circuit is $11.72 \%$.

Table 1. Setting IGBT ignition angle

\begin{tabular}{ccc}
\hline Gating Block & IGBT & Ignition Angle (") \\
\hline G1 & $1 \& 4$ & $5-175$ \\
G2 & $2 \& 3$ & $185-355$ \\
G3 & $5 \& 8$ & $15-165$ \\
G4 & $6 \& 7$ & $195-345$ \\
G5 & $9 \& 12$ & $25-155$ \\
G6 & $10 \& 11$ & $205-335$ \\
G7 & $13 \& 16$ & $35-145$ \\
G8 & $14 \& 15$ & $215-325$ \\
G9 & $17 \& 20$ & $45-135$ \\
G10 & $18 \& 19$ & $225-315$ \\
G11 & $29 \& 32$ & $55-125$ \\
G12 & $30 \& 31$ & $235-305$ \\
G13 & $26 \& 27$ & $245-295$ \\
G14 & $25 \& 28$ & $65-115$ \\
G15 & $22 \& 23$ & $255-285$ \\
G16 & $21 \& 24$ & $75-105$ \\
\hline
\end{tabular}

\subsection{Filter design}

The source impedance strongly affect the filtering characteristics. It causes system resonance in passive filter application. These drawbacks can be removed by introducing a combination of active and passive power filters with appropriate coordination. The LCL passive filter is used in design due to its high filtering performance. LCL filter minimizes cost, size and weight. Moreover, LCL filter is suitable to meet harmonic constraints as defined by standard IEEE 519 [28]. The designed active filter control is performed by using current sensors, summing amplifiers and inverting amplifiers. The current sensor detects the changing current and transmits its waveforms to the summing amplifier. The current waveform 
is a reference wave to be compared to the sine waveform generated by the oscillator. The comparison result is the current waveform that is injected into the circuit as compensation.

The inverting amplifier circuit serves as a voltage inverter for the phase voltage generated by a sine wave oscillator. This sine wave is $180^{\circ}$ phase different from the sine wave generated by the oscillator. The inverting amplifier circuit adjusts the IGBT startup angle and the summing amplifier circuit controls the compensation current. The active filter used in this work is an active shunt filter. The topology is depicted in Figure 4. Input filter is taken from the driver inverter, and the output filter is connected to the load. The active shunt filter injects the compensation current into the circuit so that the THDi value in the injected circuit improves.

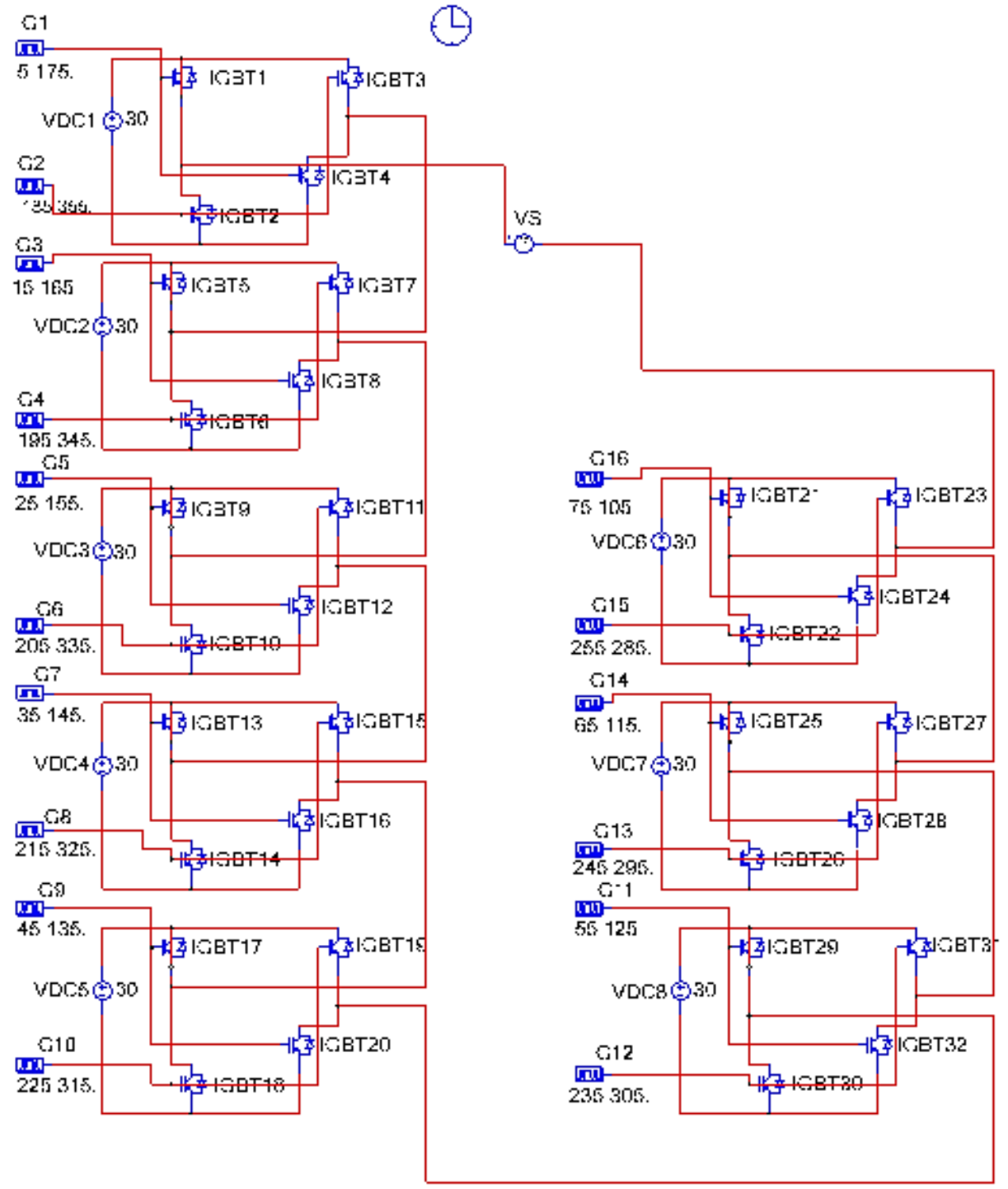

Figure 2. The multilevel inverter simulation circuit

The active shunt filter uses a voltage source inverter (VSI) and the inverter type is the H-bridge inverter. The H-bridge inverter is driven by the generated harmonics. The SPWM generator is used to ignite the IGBTs. The single-phase full-bridge inverter is arrange in series of sinus generators (oscillators). The output is then compared to the output waveform of the summing amplifier. Afterward, the current injection flows through the Lf inductor. The driver and the compensation circuits are shown in Figure 5.

The LCL filter circuit design is shown in Figure 6. The value of $\mathrm{C}$ is determined based on values $0.0001 \mathrm{~F}$ or $100 \mu \mathrm{F}$. The cutoff frequency is determined $50 \mathrm{~Hz}$ as the power frequency of the intended application. Then inductor value, $\mathrm{L}$ is determined by using (2) [1]. 
$f_{\text {cut off }}=\frac{1}{2 \pi} \sqrt{\frac{L_{1}+L_{2}}{L_{1} \cdot L_{2} \cdot C}}$

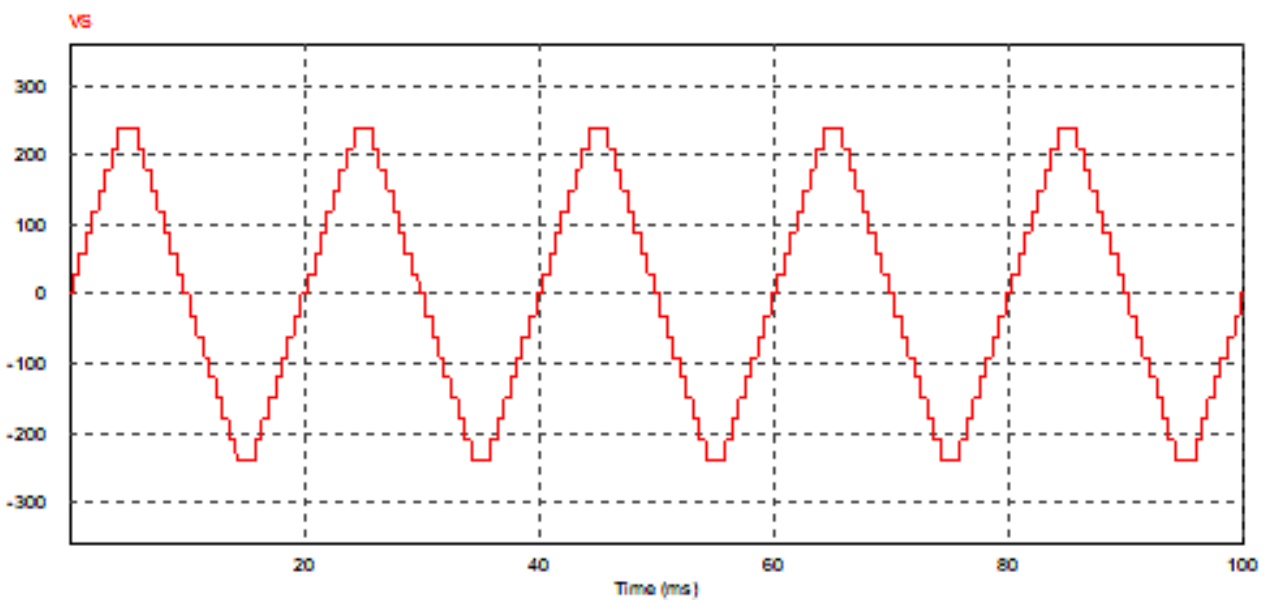

(a)

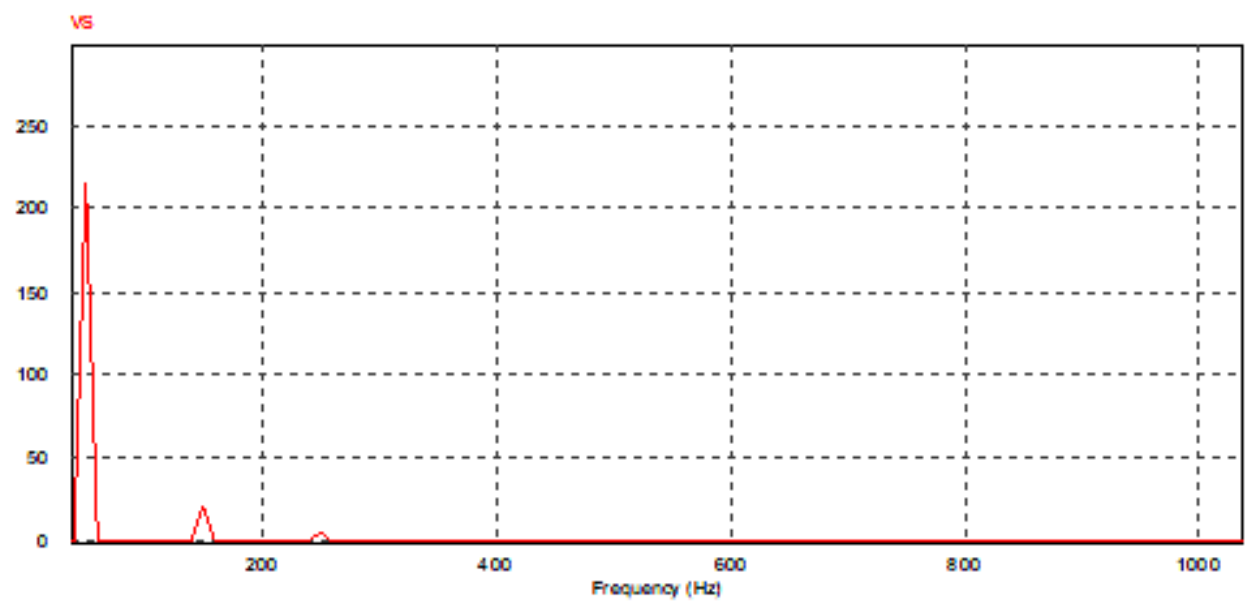

(b)

Figure 3. Output voltage waveform and its harmonic spectrum, (a) Voltage waveform, (b) Harmonic spectrum

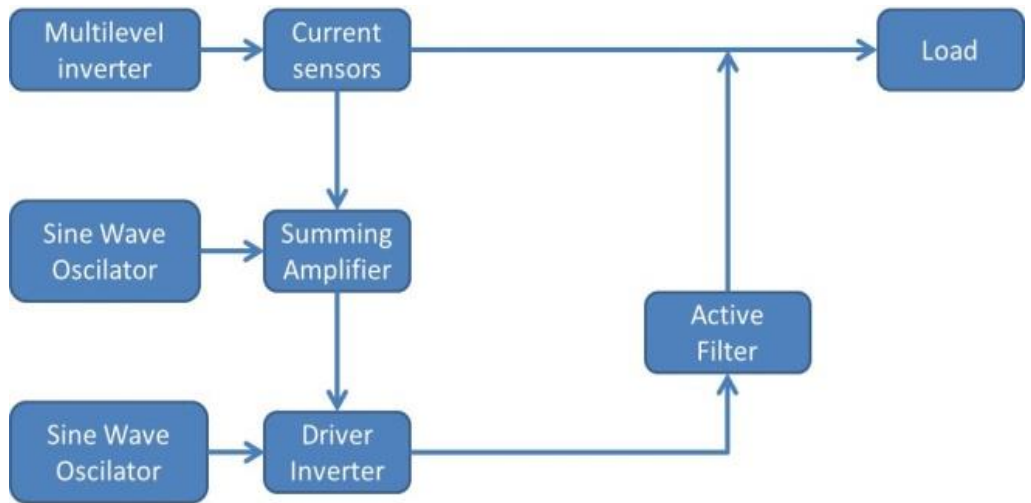

Figure 4. Block diagram of the active filter 


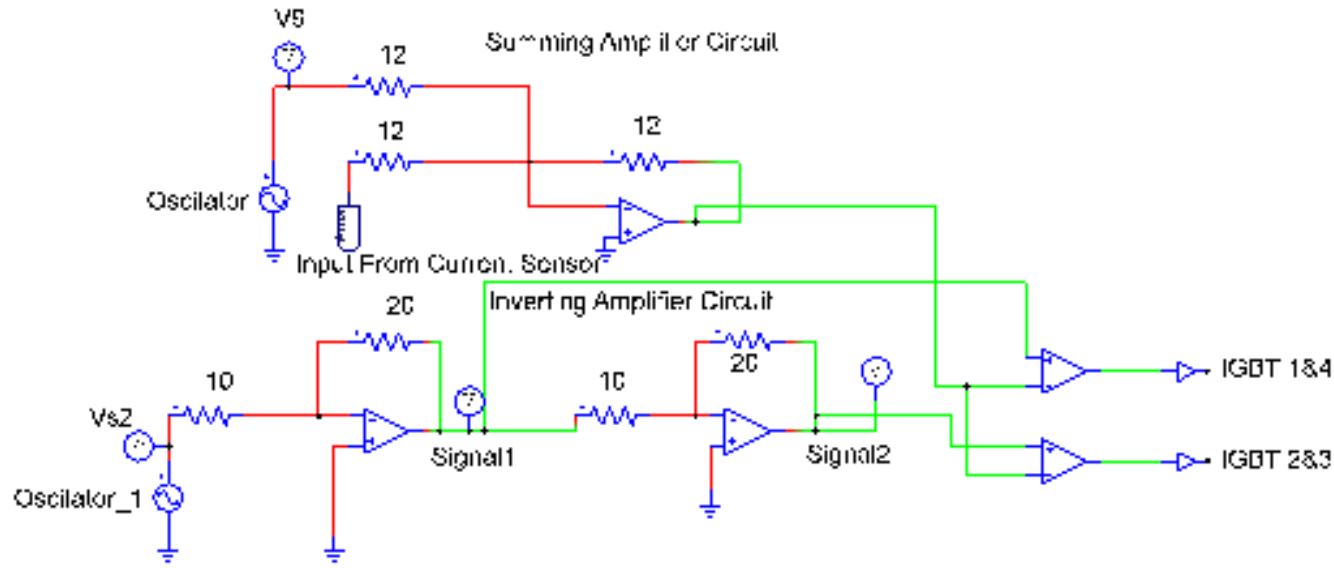

(a)

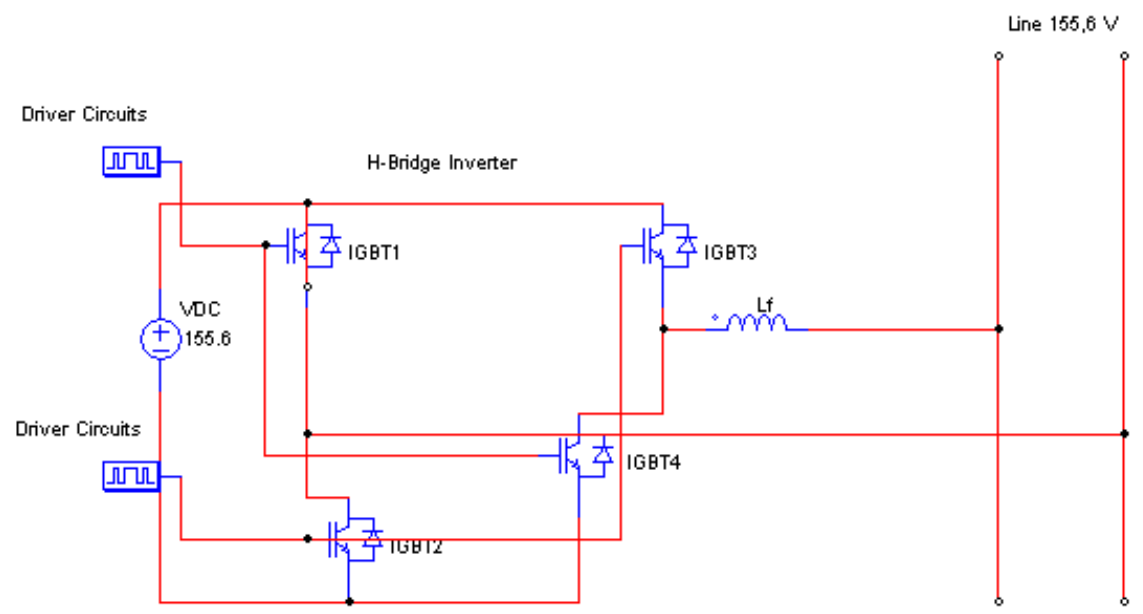

(b)

Figure 5. Driver series of IGBT SPWM one phase inverter, (a) Driver circuit, (b) Injection current

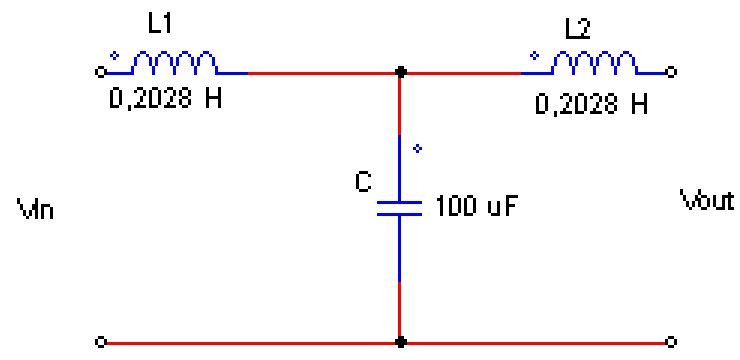

Figure 6. LCL filter

\section{CIRCUIT TESTING}

The multilevel inverter cascaded circuit is tested by using linear load and non-linear load. Linear load uses a resistor, while non-linear load uses RL load, a step-up transformer and a single-phase full-bridge converter. Load test parameters are plotted in Table 2. The linier load is made of a $12 \Omega$. This value is selected to avoid over current flows in the designed circuit. The RL non-linear load is by using a $12 \Omega$ resistor and a $10 \mathrm{mH}$ inductor. The transformer load is an asymmetric primary and secondary turns (step-up). Finally, the full bridge converter is also connected to $12 \Omega$ resistor.

The overall circuit blocks are depicted in Figure 7. The cascaded multilevel inverter is arranged in parallel to the active filter and the passive filter and is arranged in series to the cascaded multilevel inverter. After the circuits have been arranged, the load is connected to the circuit. 
Table 2. Load test parameters

\begin{tabular}{cc}
\hline Type ofload & Value of load \\
\hline R Load & $\mathrm{R}=12 \Omega$ \\
R-L Load & $\mathrm{R}=12 \Omega$ and $\mathrm{L}=10 \mathrm{mH}$ \\
TransformerLoad & $\mathrm{Np}=200$ and $\mathrm{Ns}=400$ \\
Full bridge converterload & $\mathrm{R}=12 \Omega$ \\
\hline
\end{tabular}

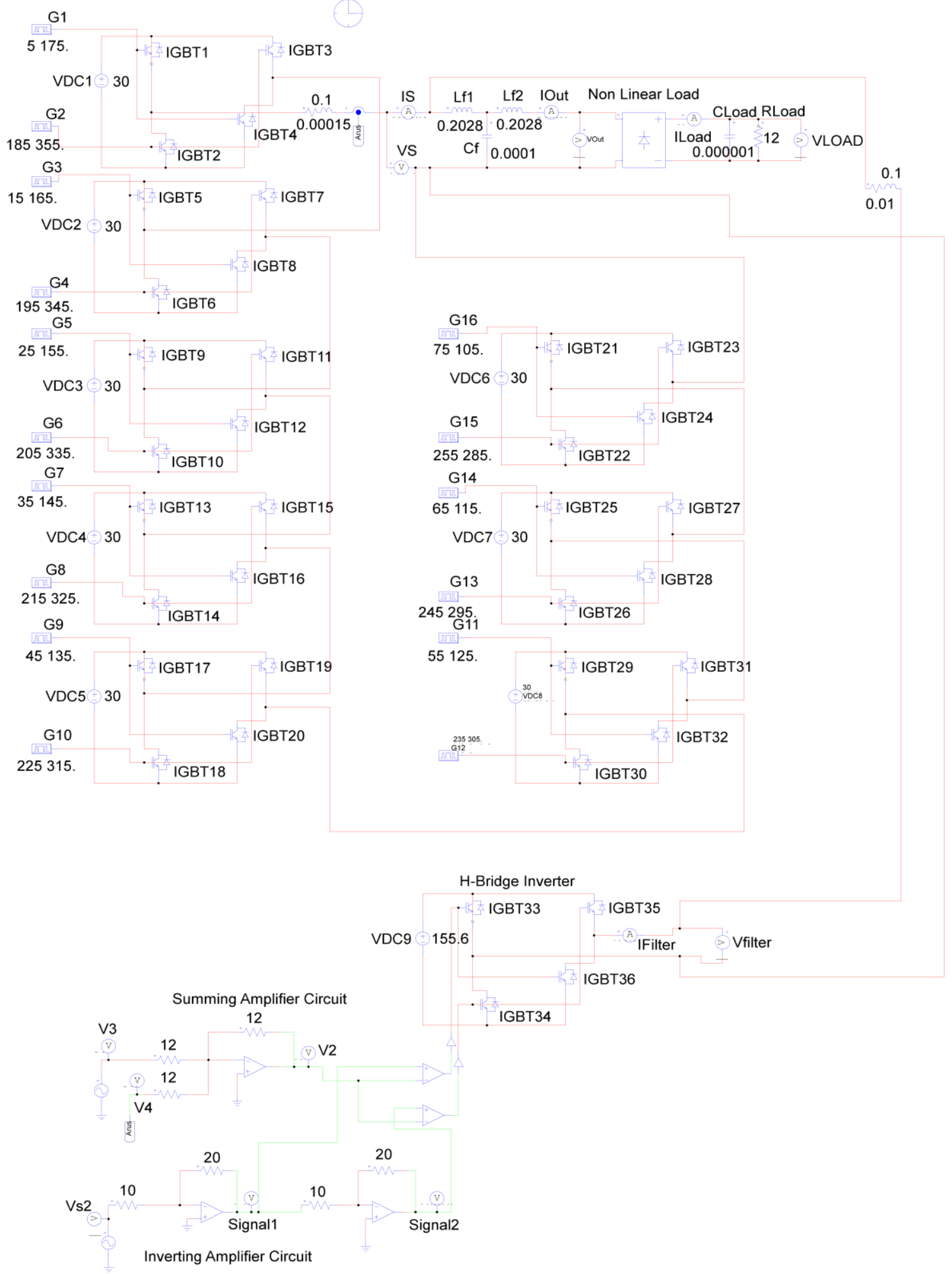

Figure 7. The overall circuit block 


\section{RESULTS AND DISCUSSIONS}

\subsection{Test results for non-filter inverter}

Test results without filter are plotted in Table 3. The waveforms are shown in Figure 8. THDv and THDi are generated higher than the permitted levels of IEEE 519-2014 which mean higher than the allowed value of $8 \%$. The test without filter produce THDv of $59.46 \%$ and THDi $59.46 \%$ for resistive load. The RL load causes higher THDv of $65.74 \%$ and lower THDi $51.59 \%$. Trafo step up generates lower THD than resistive load, while the converter provides lower THDv but similar THDi to resistive load.

Table 3. Test results for non-filter inverter

\begin{tabular}{cccc}
\hline No & Type ofload & THDv & THDi \\
\hline 1 & R & $59.46 \%$ & $59.46 \%$ \\
2 & RL & $65.74 \%$ & $51.59 \%$ \\
3 & Trafo step up & $58.55 \%$ & $58.14 \%$ \\
4 & Full bridge converter & $59.34 \%$ & $59.46 \%$ \\
\hline
\end{tabular}
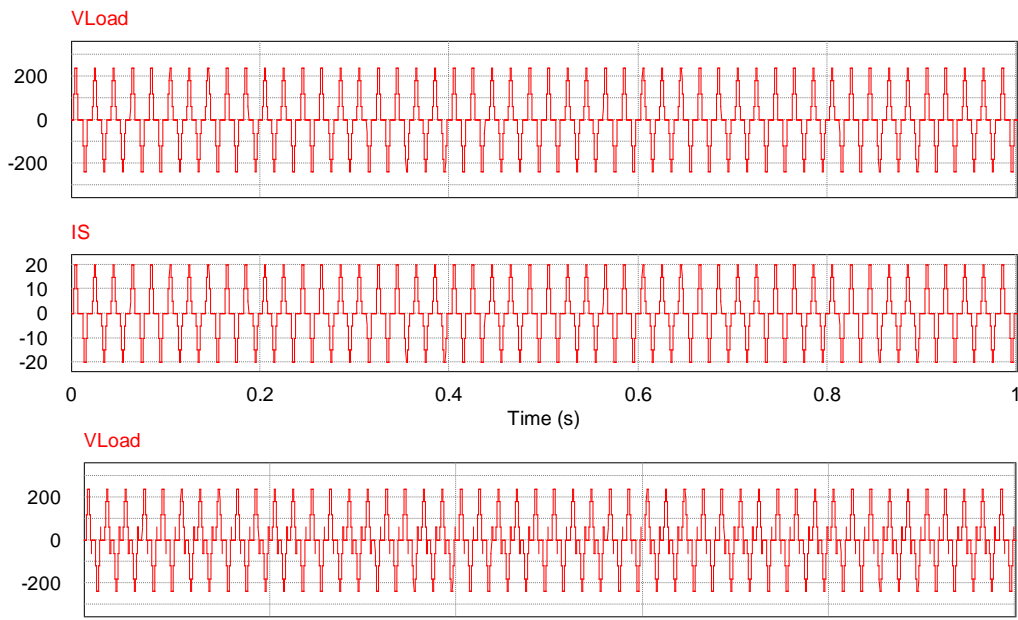

(a)

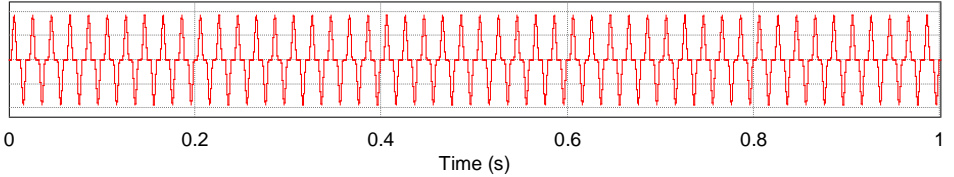

VLoad

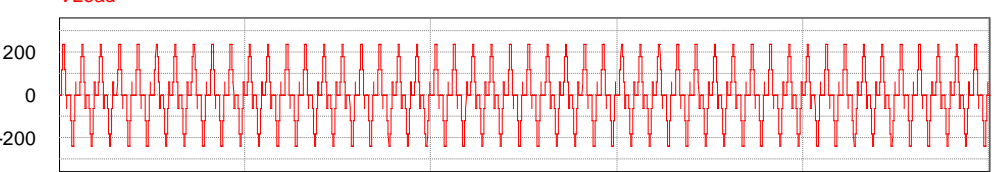

(c)

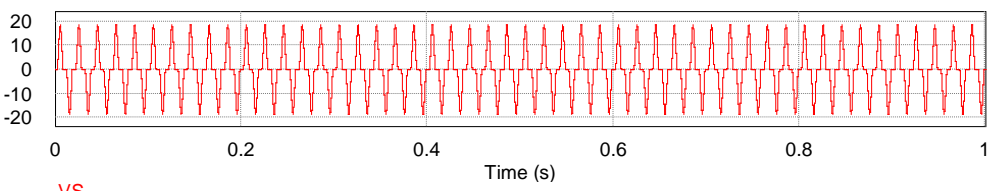

VS

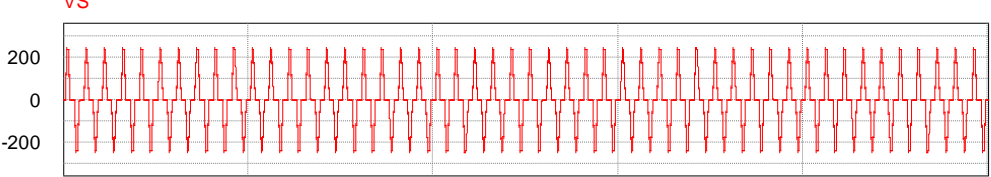

(d)

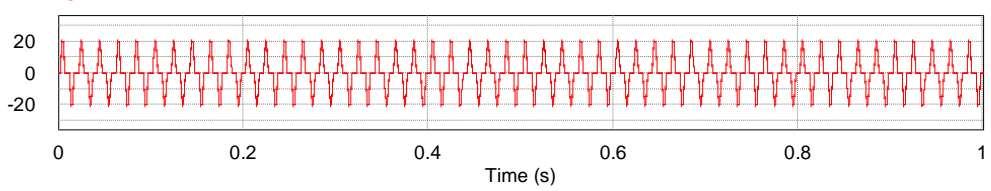

(b)

Figure 8. Non-filter test results, (a) R load, (b) RL load, (c) Step-up transformer load, (d) Converter load 


\subsection{Test results for hybrid filter inverter}

The multilevel inverter cascaded circuit is coupled with a hybrid filter and then connected to the same load as previous test. The generated waveforms can be seen in Figure 9. The THD values are at the permitted levels of IEEE 519-2014. The generated waveforms after filtering become sinusoidal.

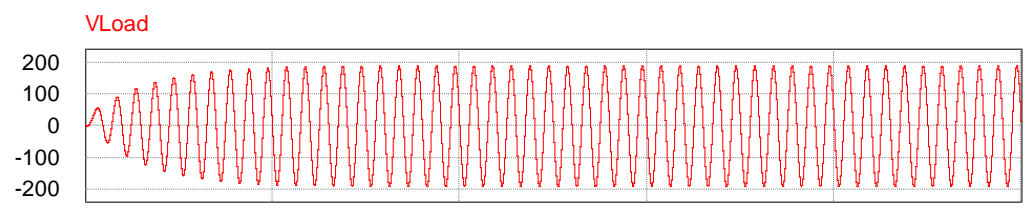

IOut

(a)

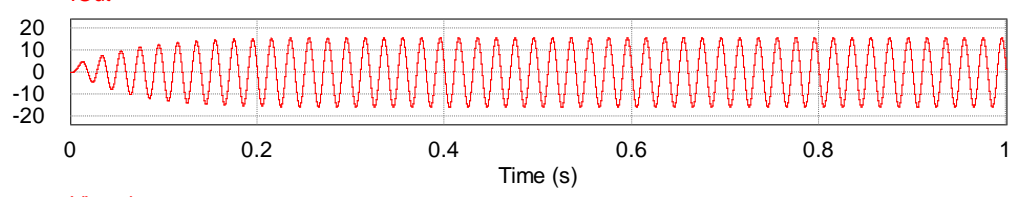

VLoad

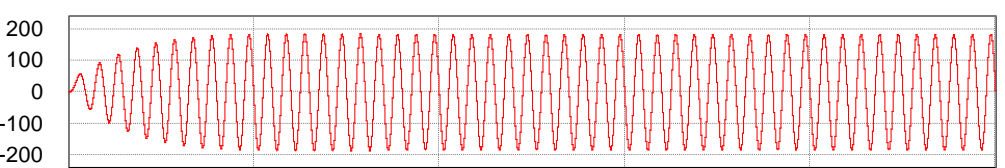

IOut

(b)

10

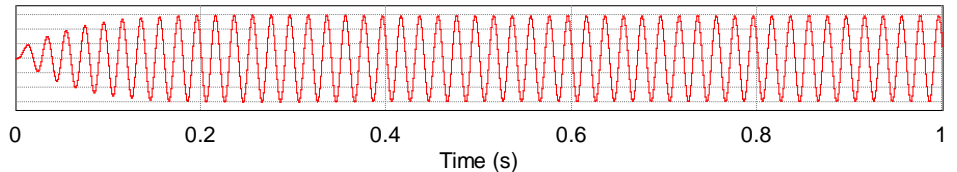

VOut

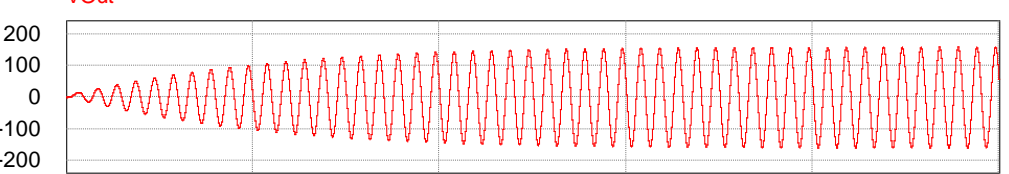

IOut

(c)

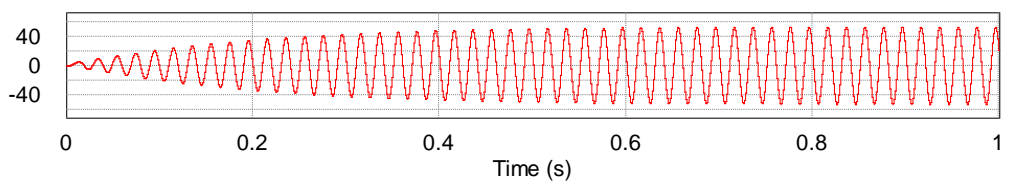

VOut

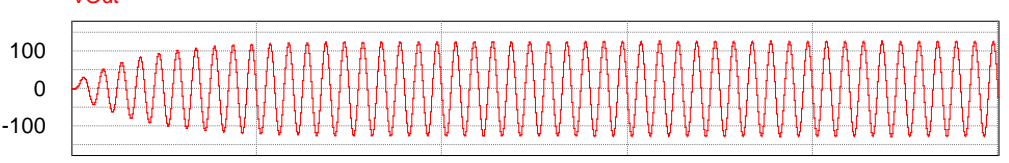

IOut

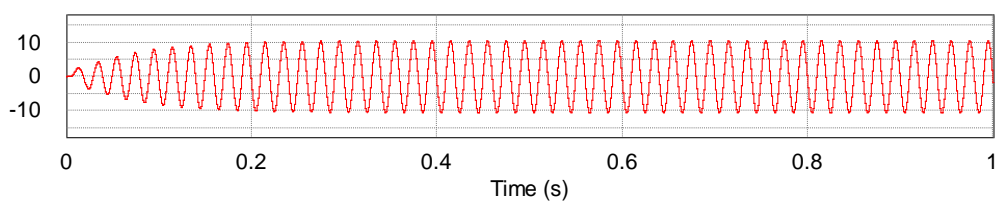

(d)

Figure 9. Test results for hybrid filter, (a) R load, (b) RL load, (c) Step up transformer load, (d) Converter load

The test results with hybrid filter installed produce THDv of $0.09 \%$ and THDi $0.09 \%$ for resistive load. The RL load produces higher THDv of $0.11 \%$ and THDi of $0.10 \%$. Trafo step up generates higher THD than $\mathrm{R}$ load, while the converter provides higher THDv but similar THDi to R load. These values are plotted in Table 4. 
Table 4. Test results using the hybrid filter

\begin{tabular}{cccc}
\hline \multirow{2}{*}{ No } & \multirow{2}{*}{ Type ofload } & \multicolumn{2}{c}{ Filter Hybrid } \\
\cline { 3 - 4 } & & THDv & THDi \\
\hline 1 & R & $0.09 \%$ & $0.09 \%$ \\
2 & RL & $0.11 \%$ & $0.10 \%$ \\
3 & Trafo Step Up & $0.23 \%$ & $1.05 \%$ \\
4 & Converter & $0.10 \%$ & $0.09 \%$ \\
\hline
\end{tabular}

\subsection{Discussion}

Simulations results show that the output waveforms of the inverter without filter are mostly non-sinusoidal with high THD values (as shown in Table 3). By adding filter, the output waveforms become sinusoidal with much lower THD values (as shown in Table 4). THDv and THDi of the inverter with filter are still within the permitted level of IEEE 519-2014 which are maximum THDv is $0.1 \%$ and maximum THDi is $1.05 \%$. The hybrid filter is significantly reducing the output harmonics up to $65.63 \%$.

On the other hand, filter addition to the inverter circuit causes transient phenomenon. Transient causes output amplitude require sometime to reach typical amplitude value. It is diffrenet from non-filter inverter that produces maximum amplitude from the beginning circuit turned on. Inductor and capasitor in filter delayed the amplitude rise. Transient process occurs as inductor and capacitor made energy exchanges. Step transformer load requires about $0.4 \mathrm{~s}$ to reach maximum amplitude, while resistive load requires the shortest one, less than $0.2 \mathrm{~s}$.

\section{CONCLUSION}

Power quality has become necessary since the renewable energy becomes circulating in the market. Since renewable energy sources are dominated by DC voltage, the inverter becomes an important device. This paper has proposed a hybrid filter insertion to the multilevel cascaded inverter to reduce voltage and currect harmonics. The assessments using PSIM simulator show that the effectiveness of proposed multilevel cascaded 17 level inverter with hybrid filter for four different load types. The filter is able to reduce the THDv and THDi up to $65.63 \%$. The active filter injected the compensation current into the circuit and the LCL filter absorbed the harmonics that occur over the $50 \mathrm{HZ}$ frequency, so that the resulting harmonics are still within the permitted level of IEEE 519-2014. On the other hand, filter drawback on the inverter output is injecting additional transient time to reach maximum amplitude as capacitor and inductor exchanges energy during filtering. Even though, the output voltage is relatively stable as transient over.

\section{REFERENCES}

[1] M. H. Rahman, M. A. Mannan, M. A. Goffer Khan, M. R. U. Karim Shovon and M. M. Haq Mamun, "Design and Implementation of a Three-Phase Inverter Operated with Different Conduction Modes," 2019 International Conference on Robotics,Electrical and Signal Processing Techniques (ICREST), Dhaka, Bangladesh, pp. 346-349, 2019.

[2] A. Vishwitha and A. K. Bhat, "Solar Based Inverter Design: A Brief Review," in Advances in Communication, Signal Processing, VLSI, and Embedded Systems, Springer, Singapore, pp. 463-469, 2020.

[3] S. Dandin and A. Kumari, "Highly Efficient Pure Sine-Wave Inverter for Photovoltaic Applications with MPPT Technique," International Journal of Engineering Research \& Technology (IJERT), vol. 3, no. 5, May 2014.

[4] M. S. Arif, S.M. Ay ob, Z. Salam, "Asy mmetrical Nine-Level Inverter Topology with Reduce Power Semiconductor Devices," Telecommunication Computing Electronics and Control, vol. 16, no. 1, pp. 38-45, Feb 2018.

[5] A. Jidin, S. Sanusi, T. Sutikno, N. R. N. Idris, "Improved Output Voltage Quality using Space Vector Modulation for Multilevel Inverters," Telecommunication Computing Electronics and Control, vol. 14, no. 2, pp. 387-389, Jun 2016

[6] N. Farah, M. H. N. Talib, J. Lazi, M. A. Ali and Z. Ibrahim, "Multilevel Inverter Fed Switched Reluctance Motors (SRMs): 6/4, 8/6 and 10/8 SRM Geometric Types," International Journal of Power Electronics and Drive Systems (IJPEDS), vol. 8, no. 2, pp. 584-592, Jun 2017.

[7] IEEE Recommended Practice and Requirements for Harmonic Control in Electric Power Systems," in IEEE Std 519-2014 (Revision of IEEE Std 519-1992), vol., no., pp.1-29, 11 June 2014

[8] S. P. Litran and P. Salmeron, "Electromagnetic Compatibility Analysis of a Control Strategy for Hybrid Active Filter," Electric Power Systems Research, Elsevier, vol. 144, pp. 81-88, Mar 2017.

[9] M. R. Sindhu, M. G. Nair and T. N. P. Nambiar, "Three Phase Auto-tuned Shunt Hybrid Filter for Harmonic and Reactive Power Compensation," Procedia Technology, Elsevier, vol. 21, pp. 482-489, 2015.

[10] F. Grasso. A. Luchetta. S. Manetti. S. De Giorgis. F. Cenghialta and E. D'Antuono, "Improving power quality and efficiency in electrical plants using a three-phase series hybrid passive filter," 2016 AEIT International Annual Conference (AEIT), Capri, pp. 1-5, 2016 
[11] V. S. R. V. Oruganti, et al., "Real-time control of hybrid active power filter using conservative power theory in industrial power svstem." IET Power Electronics. vol. 10. no. 2. pv. 196-207. 2017.

[12] S. Sellakumar, et al., "Dynamic Hybrid Shunt Active Filter to Reduce the THD in $415 \mathrm{~V}, 50 \mathrm{~Hz}$ Distribution System," National Journal on Electronic Sciences and Systems, vol. 4, no. 1, 2013.

[13] G. Tsengenes, T. Nathenas and G. Adamidis, "A three-level space vector modulated grid connected inverter with control scheme based on instantaneous power theory," Simulation Modelling Practice and Theory, vol. 25, pp. 134-147. Jun 2012.

[14] C. C. Hua and C. W. Chuang, "Design and implementation of a hybrid series active power filter," in 2005 International Conference on Power Electronics and Drives Systems, vol. 2, pp. 1322-1326, 2005.

[15] Yongqiang Lang, Dianguo Xu, S. R. Hadianamrei and Hongfei Ma, "A Novel Design Method of LCL Type Utility Interface for Three-Phase Voltage Source Rectifier," 2005 IEEE 36th Power Electronics Specialists Conference, Recife, pp. 313-317, 2005.

[16] W. Tang, Y. Song, R. Cheng and K. Ma, "Current Ripple Oriented Design of LCL Filter for Three-Phase VoltageSource Converter with Different Wire Connections and Modulations," 2018 IEEE Energy Conversion Congress and Exposition (ECCE), Portland, OR, 2018, pp. 5887-5891.

[17] X. Shi, Z. Wang, Y. Ma, L. Hang, L. M. Tolbert and F. Wang, "Modeling and control of an LCL filter based threephase active rectifier in grid emulator," 2013 Twenty-Eighth Annual IEEE Applied Power Electronics Conference and Exposition (APEC), Long Beach, CA, 2013, pp.992-998.

[18] Yong-Sin Jin, Hee-Keun Shin, Hag-Wone Kim, Kwan-Yuhl Cho and Byung-Kook Lim, "A carrier comparison PWM method for reducing input current THD of three-phase PWM rectifier," Proceedings of The 7th International Power Electronics and Motion Control Conference, Harbin, 2012, pp. 3015-3020.

[19] A. Marzouki, M. Hamouda and F. Fnaiech, "Sensorless nonlinear control for a three-phase PWM AC-DC converter," 2010 IEEE International Symposium on Industrial Electronics, Bari, 2010, pp. 1052-1057.

[20] A. Marzouki, M. Hamouda and F. Fnaiech, "A hybrid controller for PWM active rectifiers based LCL filters," COMPEL: The International Journal for Computation and Mathematics in Electrical and Electronic Engineering, vol. 34, no. 4, pp. 1229-1251, Jul 2015.

[21] P. Thirumoorthi and N. Yadaiah. "Desion of current source hvbrid power filter for harmonic current compensation," Simulation Modelling Practice and Theory, vol. 52, pp. 78-91, Mar 2015.

[22] B. Singh, V. Verma, A. Chandra and K. Al-Haddad, "Hybrid filters for power quality improvement," in IEE Proceedings - Generation, Transmission and Distribution, vol. 152, no. 3, pp. 365-378, 6 May 2005.

[23] G. N. Rao, P. S. Raju, K. C. Sekharc, "Harmonic Elimination of Cascaded H-Bridge Multilevel Inverter Based Active Power Filter Controlled By Intelligent Techniques," International Journal of Electrical Power and Energy Systems, Elsevier, vol. 61, pp. 56-63, Oct 2014

[24] C. Bharatiraja and Latha, "A New Asymmetrical Single Phase 15 Level Reduced Switch Multilevel Voltage Source Inverter," Journal of Electrical Engineering, vol. 15, pp. 1-9, Jan 2015.

[25] C. H. Cheng, "Design of Output Filter for Inverter Using Fuzzy logic," Expert Systems with Applications: An International Journal, vol. 38, no 7, pp. 8639-8647, Jul 2011.

[26] V. A. Lacerda, D. V. Coury and R. M. Monaro, "LCL Filter Design For VSC-HVDC Systems Supplying Passive Grids," Electric Power Systems Research, Elsevier, vol. 152, pp. 160-167, Nov 2017.

[27] M. Venkatesan, R. Rajeswari, M. Kaliy amoorthy, M. Srithar, "Transient and Steady State Analy sis of Modified Three Phase Multilevel Inverter for Photovoltaic System," International Journal of Power Electronics and Drive Systems, vol. 8, no. 1, pp. 31-39, Mar 2017.

[28] M. B. Saïd-Romdhane, M. W. Naouar, I. S. Belkhodja and E. Monmasson, "Simple and Systematic LCL Filter Design for Three-Phase Grid-Connected Power Converters," Mathematics and Computers in Simulation, Elsevier, vol. 130, pp. 181-193, Dec 2016.

\section{BIOGRAPHIES OF AUTHORS}

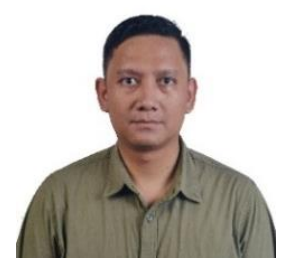

Marshal Andrea Hutabarat is finished his Master of Engineering (MEng) in electrical engineering from University of North Sumatera in 2017. He receives a scholarship from his institution for his Master of Science (MSc) degree which he is currently pursuing in The Australian National University (ANU) in Business Information Sy stem.

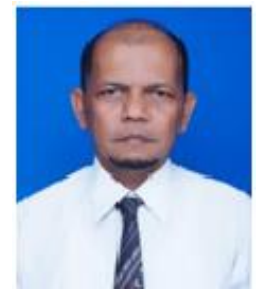

Syafruddin Hasan was born in July 1, 1959 in Pidie, Aceh-Indonesia. He received his BSc from Universitas Sumatera Utara (USU) Medan in 1985, M Sc from Institut Teknologi Bandung (ITB) Bandung-Indonesia in 1993, and PhD from Universiti Malaysia Perlis (UniMAP) in 2014, all in Electrical Engineering. He is a lecture in USU. His field of interest includes Electromagnetic Theory, Electrical Machines, Power Electronic Drives and Power Quality. 


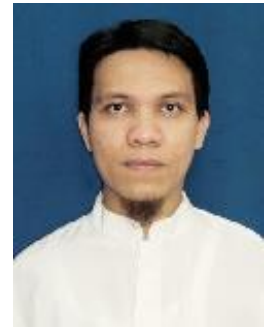

Ali Hanafiah Rambe received his BSc from Universitas Sumatera Utara, Indonesia, MSc from Universitas Indonesia, and PhD from Universitas Sumatera Utara His field of interest includes Electromagnetic Theory, Transmission Lines, and Antennas.

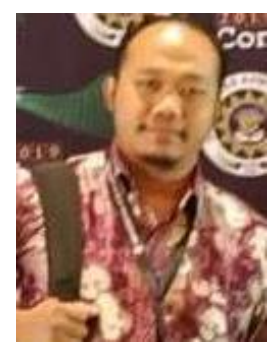

Suherman completed BSc in Electrical Engineering, Universitas Sumatera Utara, Indonesia in 2000, MSc in Networked and Distributed System, RMIT, Australia in 2009, and PhD in Electrical and Electronics Engineering from De Montfort University, UK in 2013. He is currently a lecturer within Electrical Engineering Department, Universitas Sumatera Utara. 